\title{
Outplanting Wyoming Big Sagebrush Following Wildfire: Stock Performance and Economics
}

\author{
Eva Dettweiler-Robinson, ${ }^{1}$ Jonathan D. Bakker, ${ }^{2}$ James R. Evans, ${ }^{4}$ Heidi Newsome, ${ }^{5}$ \\ G. Matt Davies, ${ }^{6}$ Troy A. Wirth, ${ }^{7}$ David A. Pyke, ${ }^{8}$ Richard T. Easterly, ${ }^{9}$ Debra Salstrom, ${ }^{10}$ \\ and Peter W. Dunwiddie ${ }^{3}$
}

Authors are ${ }^{1} \mathrm{PhD}$ Student, Department of Biology, University of New Mexico, Albuquerque, NM 87131, USA; ${ }^{2}$ Associate Professor and ${ }^{3}$ Affiliate Professor, School of Environmental and Forest Sciences, University of Washington, Seattle, WA 98195, USA; ${ }^{4}$ Stewardship Coordinator, The Nature Conservancy, Seattle, WA 98101, USA; ${ }^{5}$ Wildlife Biologist, US Fish and Wildlife Service, Mid-Columbia River National Wildlife Refuge Complex, Burbank, WA 99323, USA; ${ }^{6}$ Lecturer, School of Interdisciplinary Studies, University of Glasgow, Crichton University Campus, Dumfries, Scotland; ${ }^{7}$ Ecologist and ${ }^{8}$ Research Ecologist, US Geological Survey, Forest and Rangeland Ecosystem Science Center, Corvallis, OR 97321, USA; and ${ }^{9}$ Ecologist and ${ }^{10}$ Botanist, Salstrom \& Easterly Eco-logic Botanical Consulting, Bellingham, WA 98229, USA.

\begin{abstract}
Finding ecologically and economically effective ways to establish matrix species is often critical for restoration success. Wyoming big sagebrush (Artemisia tridentata subsp. wyomingensis) historically dominated large areas of western North America, but has been extirpated from many areas by large wildfires; its re-establishment in these areas often requires active management. We evaluated the performance (survival, health) and economic costs of container and bare-root stock based on operational plantings of more than 1.5 million seedlings across 2200 ha, and compared our plantings with 30 other plantings in which sagebrush survival was tracked for up to 5 yr. Plantings occurred between 2001 and 2007, and included 12 combinations of stock type, planting amendment, and planting year. We monitored 10500 plants for up to 8 yr after planting. Survival to Year 3 averaged $21 \%$ and was higher for container stock $(30 \%)$ than bare-root stock $(17 \%)$. Survival did not differ among containerstock plantings, whereas survival of bare-root stock was sometimes enhanced by a hydrogel dip before planting, but not by mycorrhizal amendments. Most mortality occurred during the first year after planting; this period is the greatest barrier to establishment of sagebrush stock. The proportion of healthy stock in Year 1 was positively related to subsequent survival to Year 3. Costs were minimized, and survival maximized, by planting container stock or bare-root stock with a hydrogel dip. Our results indicate that outplanting is an ecologically and economically effective way of establishing Wyoming big sagebrush. However, statistical analyses were limited by the fact that data about initial variables (stock quality, site conditions, weather) were often unrecorded and by the lack of a replicated experimental design. Sharing consistent data and using an experimental approach would help land managers and restoration practitioners maximize the success of outplanting efforts.
\end{abstract}

Key Words: Artemisia tridentata subsp. wyomingensis, bare-root stock, container stock, cost-benefit analysis, planting amendments, sagebrush restoration

\section{INTRODUCTION}

When one is restoring degraded sites, the establishment of matrix or dominant species is a priority, because these species provide essential structure and functions. Depending on the life-history traits of these species, establishment might be accomplished by adding plants as seed, seedlings, or vegetative starts. Successful restorations should use techniques that are both ecologically effective at establishing species and economically cost effective (Boyd and Davies 2012).

Research was funded by the US Fish and Wildlife Service, US Geological Survey, and Joint Fire Science Program (project JFSP 08-1-5-20).

Any use of trade, product, or firm names is for descriptive purposes only and does not imply endorsement by the US Government.

At the time of research, Dettweiler-Robinson was a Research Assistant, and Davies was a Post-Doctoral Research Associate, School of Environmental and Forest Sciences, University of Washington, Seattle, WA 98195, USA.

Correspondence: Jonathan D. Bakker, School of Environmental and Forest Sciences, University of Washington, Seattle, WA 98195, USA. Email: jbakker@u.washington. edu

Manuscript received 28 August 2012; manuscript accepted 2 September 2013.

(c) 2013 The Society for Range Management
In many arid and semiarid environments, shrubs form the matrix vegetation. In shrub-steppe ecosystems throughout western North America, big sagebrush (Artemisia tridentata Nutt.) is a matrix species that affects ecosystem functions such as water utilization and storage, biomass production, and nutrient cycling (Link et al. 1990; Welch 2005), and provides food, shelter, nest sites, and other critical habitat components for fauna (Connelly et al. 2000; Vander Haegen et al. 2000). Unfortunately, wildfires have become more frequent and extensive in low-elevation shrub-steppe ecosystems as invasive annual grasses such as cheatgrass (Bromus tectorum L.) have altered the structure and continuity of fuels (Brooks et al. 2004). This is problematic in part because big sagebrush is easily killed by fire and cannot resprout. Furthermore, big sagebrush seed has limited dispersal ability and persistence in the soil (Young and Evans 1989, but see Wijayratne and Pyke 2012), so the rate at which this species re-establishes in burned areas is dependent on the size of the fire and distance to surviving individuals.

Big sagebrush can be direct seeded by drilling or broadcasting. However, these methods often require soil disturbance to 
ensure good seed-soil contact and therefore are more appropriate when establishing new communities (e.g., mine reclamation; Schuman et al. 2005) than when rehabilitating areas containing desirable species that would be damaged by such methods. Planting nursery-grown stock may be a more successful approach in areas where soil disturbance is undesirable. Furthermore, strong variation in climatic and biophysical conditions in semiarid ecosystems (e.g., Augustine 2010) can affect seed germination and establishment (MacDougall et al. 2008; McAdoo et al. 2013) and therefore sagebrush seedings can have limited success (Lysne and Pellant 2004). This heterogeneity in establishment in the field can be avoided by allowing seeds to germinate and establish under controlled conditions in a nursery. Thus, use of outplanted nursery-grown stock may be more reliable than direct seeding if survival rates of the outplanted stock are sufficiently high. The larger size of nursery-grown stock at planting should also accelerate the development of desired habitat structure.

Restoration of shrub steppe in the western United States, particularly following fire, frequently includes outplanting of sagebrush stock (e.g., North States Burned Area Emergency Rehabilitation Team [NSBAER] 2000). Significant funds are expended each year on such efforts, although to our knowledge no rigorous studies have examined their success across a range of sites, years, and conditions. Robust conclusions about the utility of nursery-grown stock require comparisons of stock performance among multiple sites and years, as well as assessments of comparative costs. We summarized data from multiple postfire outplantings of A. tridentata Nutt. subsp. wyomingensis Beetle \& Young (Wyoming big sagebrush) seedlings in Washington. We synthesized data from these restoration efforts to quantify the survival and growth of container and bare-root (BR) stock up to $8 \mathrm{yr}$ after planting, calculated costs associated with the different outplantings, and explored the utility of early measures of seedling health in predicting future survival. In addition, we compiled and analyzed survival data from Wyoming big sagebrush outplantings reported in the literature. Results of this study are applicable for the use of planting stock in general and for the restoration of shrub-steppe ecosystems in particular.

\section{METHODS}

\section{Study Area}

The Hanford Reach National Monument (HRNM) in southcentral Washington (lat $46.5^{\circ} \mathrm{N}$, long $119.6^{\circ} \mathrm{E}$ ) is comanaged by the US Fish and Wildlife Service (USFWS) and US Department of Energy. HRNM is located within the Columbia Plateau ecoregion (US Environmental Protection Agency [US EPA] 2010). Annual precipitation averages $181 \mathrm{~mm}$, with only $11 \%$ falling during the summer (Hanford Meteorological Station [HMS] 2011). The average annual temperature is $11.9^{\circ} \mathrm{C}$; July is the warmest month $\left(24.8^{\circ} \mathrm{C}\right)$ and January the coldest $\left(-0.4^{\circ} \mathrm{C}\right)$.

Historically, the vegetation of HRNM was shrub steppe dominated by Wyoming big sagebrush and perennial bunchgrasses. Wildfires over the last $60 \mathrm{yr}$, including notable fires in 2000, 2005, 2006, and 2007, have eliminated Wyoming big sagebrush from much of HRNM (Evans and Lih 2005; Davies et al. 2012).

\section{Restoration Design and Monitoring}

Outplantings of nursery-grown sagebrush stock occurred within a year or two of wildfires, with goals of 1) restoring sagebrush to habitats where it had been removed by fire but were otherwise relatively intact, 2) enhancing the connectivity of remnant sagebrush patches, and 3) establishing seed sources to promote passive recolonization of surrounding areas (Longland and Bateman 2002). Outplantings and monitoring occurred before this study was conceived, so there were unavoidable differences among planting years in sampling design, choice of stock type and planting amendment, and monitoring protocols as discussed below. In addition, some data that would have been helpful were unavailable. For example, although seedlings met minimum stock quality specifications, as discussed below, quality was not assessed on individual seedlings. Nonetheless, the resulting data reflect real, on-the-ground decisions of land managers and address a significant gap in the literature about the effectiveness of planting Wyoming big sagebrush stock.

Seedlings were grown as container and BR stock in commercial and government nurseries from seed collected in the Columbia Basin. All stock was grown in the nursery for one growing season and cold hardened for dormancy prior to delivery. Container stock was of two cell volumes, $66 \mathrm{~cm}^{3}$ (e.g., RLC4 cone-tainers ${ }^{\circledR}$ ) and $164 \mathrm{~cm}^{3}$ (e.g., SC10 cone-tainers ${ }^{\circledR}$ ), and are referred to here as small and large, respectively. Container stock received an endomycorrhizal inoculant in the nursery. Stock specifications required that container seedlings have root systems that filled the cell at the time of outplanting and a stem height of at least $5 \mathrm{~cm}$. Mean stem height at the time of planting was estimated at $6 \mathrm{~cm}$ for small plants and $11 \mathrm{~cm}$ for large plants. BR stock was grown in nursery beds, lifted in the fall, and held in cold storage until planting. Stock specifications required that BR stock have a minimum stem height of $15 \mathrm{~cm}$ and root length of $15 \mathrm{~cm}$. BR stock was untreated or received up to two of the following amendments immediately before planting: a hydrogel root dip $(\mathrm{H}$; TerraSorb ${ }^{\circledR}$ Fine-Grade Hydrogel; Plant Health Care, Inc., Pittsburgh, PA), inoculation with mycorrhizae as a root dip (MD; MycoApply ${ }^{\circledR}$ Root Dip Gel; Mycorrhizal Applications, Inc., Grants Pass, OR), or inoculation with mycorrhizae as a tablet placed in the planting hole (MT; Plant Success ${ }^{\circledR}$ Tablets; Mycorrhizal Applications). The combinations of stock type, amendment, and planting year included in this study are summarized in Table 1.

Seedlings were outplanted by experienced contractors with the use of standard equipment (hoedads, planting shovels) and practices in late fall or early winter (November-January), and received no irrigation or other treatments after outplanting. Planting sites had gentle slopes, usually had silt loam soils, and ranged from $190 \mathrm{~m}$ to $440 \mathrm{~m}$ in elevation (Table 1). More than 1.5 million seedlings were planted across $\sim 2200$ ha during the planting years of 2001, 2002, 2005, 2006, and 2007 (Table 1). Here, we index all monitoring relative to the planting year (Year 0), with Year 1 referring to monitoring that occurred during the first growing season after outplanting. For example, 
Table 1. Monitoring intensity by SAY (combination of stock type, amendment, and planting year). For each SAY, the elevation range, soil texture class, and slope are summarized along with the number of plots monitored, number of seedlings monitored $(N)$, total number of seedlings planted, and total area planted.

\begin{tabular}{|c|c|c|c|c|c|c|c|c|}
\hline Stock + amendment ${ }^{1}$ & Year $^{2}$ & Elevation $(\mathrm{m})$ & Soil texture class ${ }^{3}$ & Slope (\%) & Plots & $N$ & Seedlings planted & Area planted (ha) \\
\hline Large & 2001 & $260-310$ & SiLo, StSiLo & $0-10$ & 5 & 556 & 22830 & 50.8 \\
\hline Small & 2001 & $240-340$ & SiLo, StSiLo & $0-10$ & 8 & 941 & 98795 & 118.3 \\
\hline Small & 2002 & $275-380$ & SiLo, StSiLo & $0-5$ & 8 & 877 & 333280 & 305.7 \\
\hline Small & 2005 & $220-265$ & LoFSa, FSa, Sa & $0-15$ & 6 & 707 & 30185 & 29.0 \\
\hline $\mathrm{BR}$ & 2006 & $190-265$ & LoFSa, FSa, Sa, D & $0-30$ & 26 & 2424 & 223560 & 247.6 \\
\hline $\mathrm{BR}$ & 2007 & $195-440$ & $\begin{array}{l}\text { SiLo, LoFSa, LoSa, } \\
\quad \text { FSa, Sa }\end{array}$ & $0-15$ & 5 & 330 & 130835 & 319.1 \\
\hline $\mathrm{BR}+\mathrm{H}$ & 2001 & $275-365$ & SiLo & $0-10$ & 5 & 495 & 52330 & 60.5 \\
\hline $\mathrm{BR}+\mathrm{H}$ & 2002 & $320-430$ & SiLo & $0-15$ & 6 & 722 & 100000 & 90.4 \\
\hline $\mathrm{BR}+\mathrm{H}$ & 2007 & $315-435$ & SiLo & $5-15$ & 15 & 1215 & 114300 & 249.8 \\
\hline $\mathrm{BR}+\mathrm{MD}$ & 2007 & $195-380$ & $\begin{array}{l}\text { SiLo, StSiLo, FSaLo, } \\
\text { LoFSa, FSa, Sa, D }\end{array}$ & $0-30$ & 5 & 450 & 227900 & 461.8 \\
\hline $\mathrm{BR}+\mathrm{MT}$ & 2007 & $250-380$ & SiLo, LoFSa, FSa, Sa & $0-15$ & 5 & 465 & 37100 & 72.4 \\
\hline $\mathrm{BR}+\mathrm{H}+\mathrm{MD}$ & 2002 & $285-430$ & SiLo & $0-20$ & 12 & 1282 & 169755 & 184.8 \\
\hline Total & & & & & 106 & 10464 & 1540870 & 2190.2 \\
\hline
\end{tabular}

${ }^{1}$ Stock sizes and amendment abbreviations: small $=66 \mathrm{~cm}^{3}$ container; large $=164 \mathrm{~cm}^{3}$ container; BR indicates bare root; $\mathrm{H}$, hydrogel; MD, mycorrhizal dip; MT, mycorrhizal tablet.

${ }^{2}$ Plot size and monitoring strategy differed between the 2001-2006 and the 2007 planting years (See Methods for details). For the 2007 planting year, the number of seedlings monitored was estimated as the mean planting density for each combination of stock type and amendment.

${ }^{3}$ Soil texture classes: D indicates dune land; FSa, fine sand; FSaLo, fine sandy loam; LoFSa, loamy fine sand; LoSa, loamy sand; Sa, sand; SiLo, silt loam; StSiLo, stoney silt loam.

seedlings that were planted in November 2001 (Year 0) were monitored during the 2002 growing season (Year 1).

Monitoring strategies were determined operationally and differed between the 2001-2006 planting years and the 2007 planting year. For the 2001-2006 planting years, permanent plots $(n=76$, across 21 sites) were established soon after planting. Each plot consisted of a single, permanently marked baseline transect. The location of each seedling within $12 \mathrm{~m}$ of the transect was recorded as the distance from the origin along the transect and the perpendicular distance from the transect. Monitoring aimed to capture at least 100 seedlings and thus, due to variation in planting density, transect area ranged from $200 \mathrm{~m}^{2}$ to $1500 \mathrm{~m}^{2}$. The number of seedlings recorded along each transect ranged from 45 to 150 (median=106). Monitoring was repeated in several years. Some plots were only

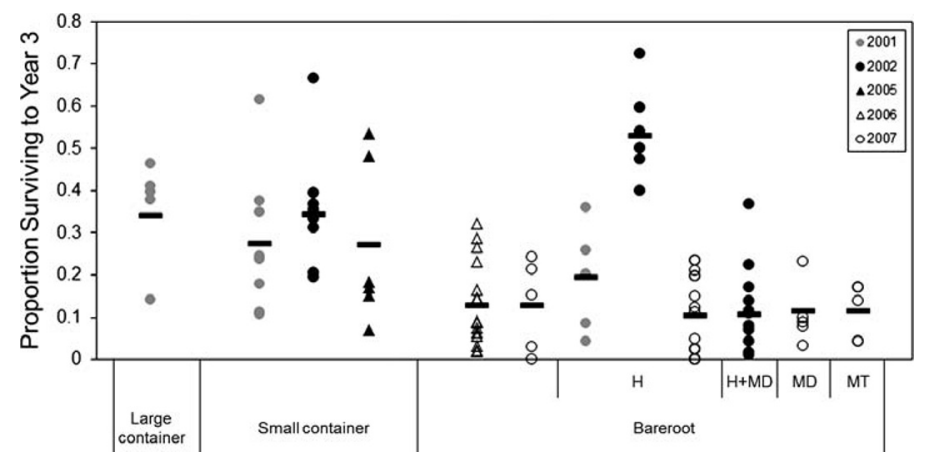

Figure 1. Proportion of seedlings surviving from planting (Year 0 ) to Year 3. Symbol color and shape distinguish planting years. Mean values for each combination of stock type (large $\left[164 \mathrm{~cm}^{3}\right.$ ] container, small [66 $\left.\mathrm{cm}^{3}\right]$ container, or bare root), amendment, and planting year (SAY) are shown by horizontal lines. Amendment abbreviations: $\mathrm{H}$ indicates hydrogel; MD, mycorrhizal dip; and MT, mycorrhizal tablet. monitored until Year 3, because many plants were killed by a subsequent wildfire; other plots were monitored up to 8 yr after planting. At each monitoring date, each seedling was relocated and its survival recorded. Seedlings that could not be relocated were recorded as missing and assumed to be dead. If missing seedlings were relocated and determined to be alive in subsequent years, previous records were modified appropriately. Those seedlings planted during the 2001 and 2002 planting years were further distinguished as healthy or stressed based on their physical appearance (healthy: green, vigorous plants; stressed: yellowed, partially defoliated, and/or with limited evidence of growth) (Evans and Lih 2005).

For the 2007 planting year, 30 plots were established across six sites. Each plot consisted of three permanently marked, 50m-long, 12-m-wide belt transects radiating out from a central point with an angle of $120^{\circ}$ between transects (see Wirth and Pyke 2011 for plot layout and monitoring details). Plots were installed and monitored in Years 1-3. Monitoring involved counting the number of live plants; the survival of individual plants was not tracked. The density of each plot at planting (Year 0) was estimated as the mean planting density for the area receiving that combination of stock and amendment (Table 1).

\section{Analyses of Performance}

In total, our data set included performance data for almost 10500 seedlings planted on 106 plots and representing 12 combinations of stock type, amendment, and planting year (combinations are abbreviated as SAYs hereafter). As noted previously, outplanting and monitoring occurred before this study was conceived and SAYs are therefore not interspersed among sites as would be possible in an experiment. This limited our ability to test for differences among stock types statistically, or to relate responses to environmental conditions. Instead, we quantified differences in survival from planting (Year 0) to Year 


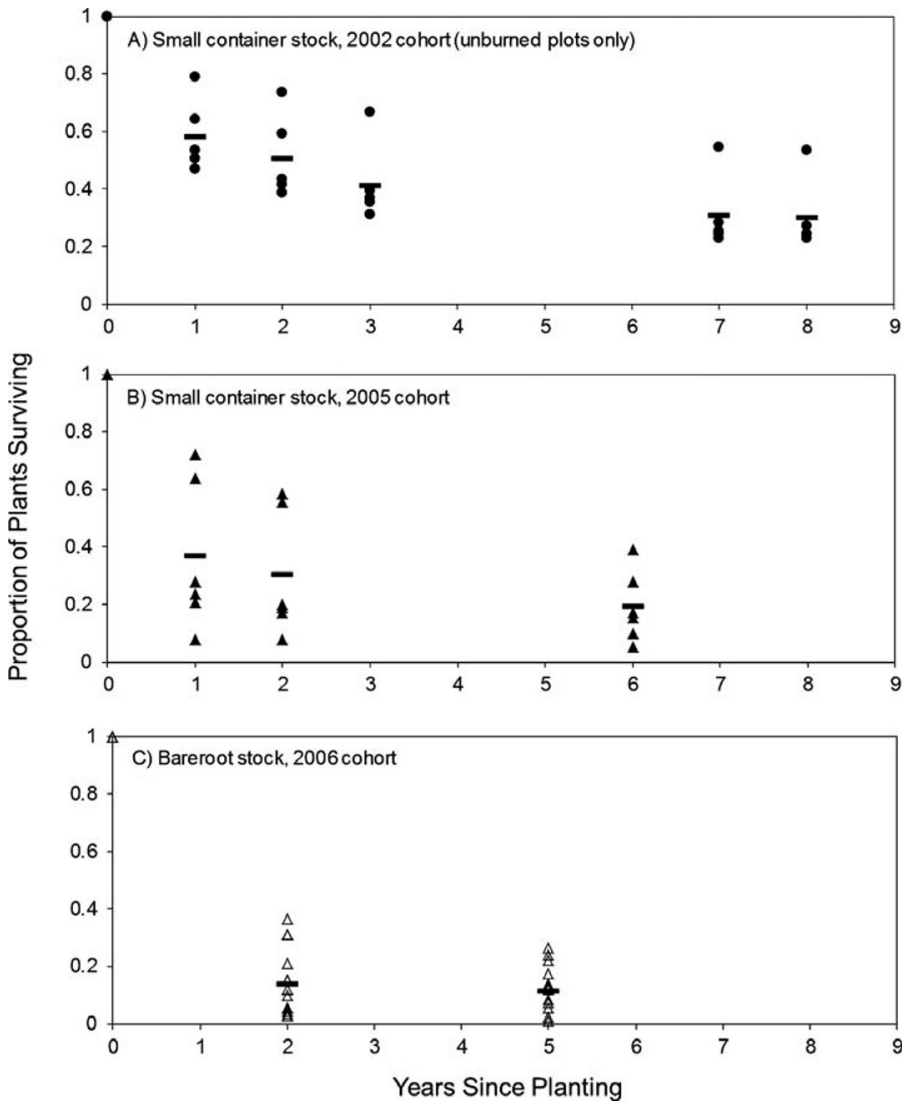

Figure 2. Survival up to $8 \mathrm{yr}$ after planting for $\mathbf{A}$, small-container stock planted in 2002; B, small-container stock planted in 2005; and C, bare-root stock planted in 2006 with no amendment. Plot data are shown as points and means as horizontal bars. Monitoring was not conducted in years without data shown.

3 for each SAY and noted broad and consistent patterns. The mean survival rate for each combination of stock type and amendment was calculated by weighting the survival rate for each planting year by the number of seedlings monitored. We graphically explored longer-term survival patterns for the subset of SAYs monitored $\geq 5 \mathrm{yr}$ after outplanting.

Using seedling condition (healthy or stressed) data, we tested whether the proportion of healthy plants in Year 1 was correlated with survival from Year 1 to Year 3. Data were analyzed via generalized linear mixed models (GLMM), with site included as a random effect and a binomial error distribution. Analysis was conducted in R 3.0.0 (R Core Team 2013). We also graphically explored whether the relationship between seedling condition in Year 1 and subsequent survival differed among SAYs.

\section{Economic Comparisons}

Three costs were compiled for each SAY: those of the seedlings themselves, the preplanting amendments they received, and their planting. Because these costs vary, for example, over time and with the number of seedlings produced, comparisons were made qualitatively. Costs were expressed on a per-plantedseedling basis as a measure of the actual costs incurred through planting. Total costs were also expressed on a per-survivingplant basis by dividing the total cost per seedling by the survival
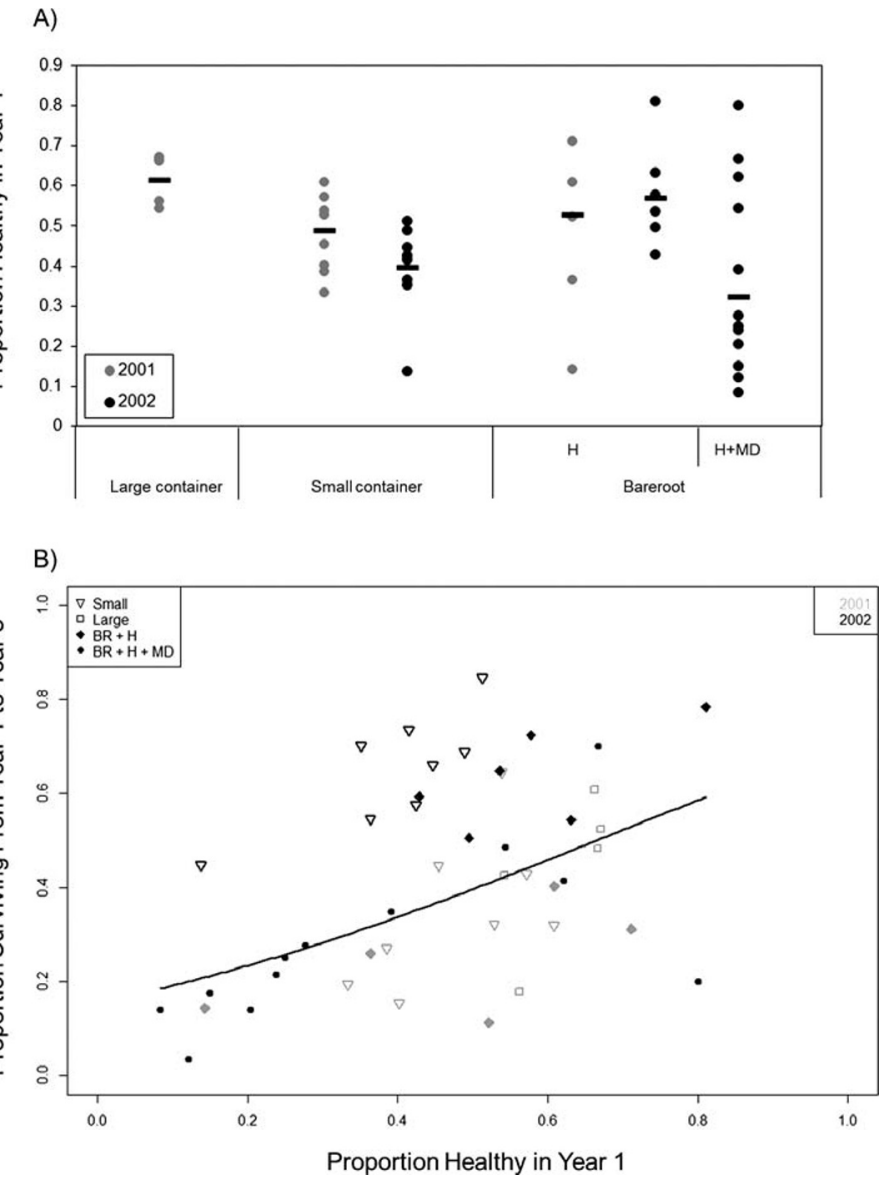

Figure 3. A, Proportion of live plants that were healthy when monitored $1 \mathrm{yr}$ after outplanting. Only those combinations of stock type, amendment, and planting year (SAY) where seedling health was measured are shown. Symbol color and shape distinguish planting years. Mean values for each combination of stock type, amendment, and planting year (SAY) are shown by horizontal lines. B, Survival from Year 1 to Year 3 as a function of the proportion of healthy plants in Year 1. Data are distinguished by SAY (stock and amendment: symbol shape and line pattern; planting year: $2001=$ grey and 2002 =black) for clarity. Plot data are shown as points; line shows predicted values from a generalized linear mixed model including proportion healthy $(P<0.001)$, with site as a random effect. BR indicates bare root; other abbreviations as in Figure 1.

rate from Year 0 to Year 3. By incorporating differential survival among SAYs, this metric provides a measure of the effective cost to establish plants. The potential for trade-offs between economic cost and restoration effectiveness was assessed by plotting costs per surviving plant against seedling survival to Year 3. For stock types planted in multiple years, mean cost and survival metrics were calculated by weighting costs by the total number of seedlings planted in each year, and weighting survival by the total number of seedlings monitored.

\section{Literature Comparison}

To put our seedling performance data in context, we compiled data from published and unpublished literature describing survival up to 6 yr after planting container and BR Wyoming big sagebrush seedlings. We restricted our focus to studies where the soil was minimally disturbed; we did not include 
Table 2. Seedling and planting costs for each combination of stock type, amendment, and planting year (SAY). All costs are on a per-plant basis and in US dollars. Stock and amendment abbreviations as in Table 1.

\begin{tabular}{|c|c|c|c|c|c|c|}
\hline $\begin{array}{c}\text { Stock + } \\
\text { amendment }\end{array}$ & Year $^{1}$ & $\begin{array}{c}\text { Seedling } \\
\text { cost }\end{array}$ & $\begin{array}{c}\text { Planting } \\
\text { cost }\end{array}$ & $\begin{array}{c}\text { Amendment } \\
\text { cost }\end{array}$ & $\begin{array}{l}\text { Total cost } \\
\text { per planted } \\
\text { seedling }\end{array}$ & $\begin{array}{c}\text { Total cost } \\
\text { per surviving } \\
\text { plant }^{2}\end{array}$ \\
\hline Large & 2001 & 0.71 & 0.20 & - & 0.91 & 2.66 \\
\hline Small & 2001 & 0.27 & 0.20 & - & 0.47 & 1.71 \\
\hline Small & 2002 & 0.27 & 0.20 & - & 0.47 & 1.37 \\
\hline Small & 2005 & 0.64 & 0.54 & - & 1.18 & 4.36 \\
\hline Small & Mean & 0.29 & 0.22 & - & 0.52 & 1.64 \\
\hline $\mathrm{BR}$ & 2006 & 0.38 & 0.21 & - & 0.59 & 4.66 \\
\hline $\mathrm{BR}^{3}$ & 2007 & 0.39 & 0.24 & - & 0.63 & 4.95 \\
\hline BR & Mean & 0.38 & 0.22 & - & 0.60 & 4.76 \\
\hline $\mathrm{BR}+\mathrm{H}$ & 2001 & 0.25 & 0.20 & 0.003 & 0.45 & 2.31 \\
\hline $\mathrm{BR}+\mathrm{H}$ & 2002 & 0.25 & 0.20 & 0.003 & 0.45 & 0.85 \\
\hline $\mathrm{BR}+\mathrm{H}^{3}$ & 2007 & 0.39 & 0.24 & 0.003 & 0.63 & 6.01 \\
\hline $\mathbf{B R}+\mathbf{H}$ & Mean & 0.31 & 0.22 & 0.003 & 0.53 & 3.33 \\
\hline $\mathrm{BR}+\mathbf{M D}^{3}$ & 2007 & 0.39 & 0.24 & 0.026 & 0.66 & 6.15 \\
\hline $\mathbf{B R}+\mathbf{M T}^{3}$ & 2007 & 0.39 & 0.24 & 0.007 & 0.64 & 5.59 \\
\hline $\mathbf{B R}+\mathbf{H}+\mathbf{M D}$ & 2002 & 0.27 & 0.20 & 0.029 & 0.50 & 4.38 \\
\hline Grand total & & 0.34 & 0.22 & 0.01 & 0.57 & 3.86 \\
\hline
\end{tabular}

${ }^{1}$ Costs are reported for each SAY. Mean costs (shown in bold) are also reported for those combinations of stock and amendment planted in multiple years, weighting costs per planted seedling by the number of planted seedlings, and costs per surviving plant by the number of seedlings monitored at planting (Year 0 ).

${ }^{2}$ Total cost per planted seedling divided by survival rate from planting to Year 3 (Tables 3 and 4).

${ }^{3}$ Initial number of seedlings was estimated from plot size and planting density.

plantings in other contexts such as mine-site reclamation (e.g., Schuman et al. 2005) or bioremediation (e.g., Lindsey and Johnson 2010), as these plantings are associated with considerable manipulation of soil structure and fertility. We classified plantings by stock type, amendment, and planting year (i.e., SAY), and also noted how many seedlings were monitored.

\section{RESULTS}

Mean survival from planting to Year 3 was $21 \%$ (Fig. 1). Container stock exhibited little variation in survival (mean$30 \%$; median $=32 \%$; range $=4-67 \%$ ). BR stock had a lower mean survival rate $(17 \%$; median $=10 \%)$ and higher variation (range $=0-73 \%$ ). SAYs had much lower mortality rates in later years than during the first year after outplanting (Fig. 2).

On average, $46 \%$ of live plants (median $=49 \%$; range: $8-$ $81 \%$ ) were classified as healthy in Year 1 (Fig. 3A). The proportion of plants that were healthy in Year 1 was positively correlated with survival from Year 1 to Year 3 (Fig. 3B).

All stock cost more to grow than to plant (Table 2). Costs per planted seedling varied more than twofold among SAYs. The cheapest SAYs were the BR $+\mathrm{H}$ and small stock planted in 2001 and 2002; the most expensive was the small stock planted in 2005. Differences among SAYs were accentuated once survival rates were factored in; costs per surviving plant in Year 3 differed almost sevenfold among SAYs (Table 2). The cheapest SAY was the BR $+\mathrm{H}$ stock planted in 2002, and the most

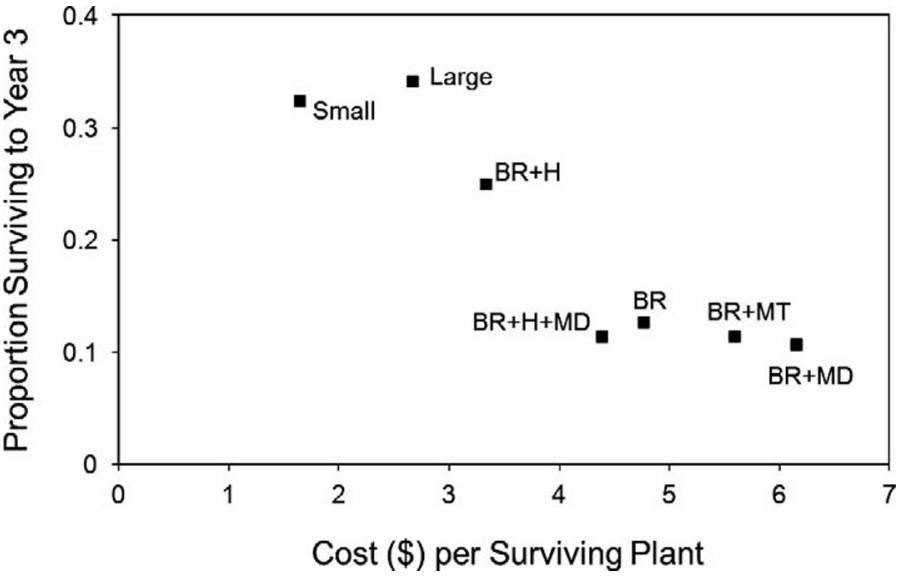

Figure 4. Survival from planting to Year 3 as a function of cost per surviving plant. Stock type and amendment combinations with low costs and high survival are preferable. For combinations planted in multiple years (Table 2), weighted average values are reported. Abbreviations as in Figures 1 and 3.

expensive were the $\mathrm{BR}+\mathrm{MD}$ and $\mathrm{BR}+\mathrm{H}$ planted in 2007. Container and $\mathrm{BR}+\mathrm{H}$ stock yielded the highest survival for the lowest cost, and untreated BR and BR that received mycorrhizal inoculation at the time of planting (MD or MT) had high costs and low survival (Fig. 4).

\section{Literature Comparison}

In total, we identified 24 container outplantings (Table 3 ) and 18 BR ouplantings (Table 4). These 42 outplantings varied considerably in sampling intensity (mean $=527$ seedlings monitored; median $=360 ;$ range $=50-2424)$ and monitoring frequency (median $=3$ times; range $=1-5$ times in the $5 \mathrm{yr}$ after outplanting). The 12 SAYs examined in our study were at the larger end of sampling intensity; results from these SAYs are likely more robust than results from SAYs monitored at lower intensities.

The most commonly used container types were $164 \mathrm{~cm}^{3}$ (13 SAYs) and $66 \mathrm{~cm}^{3}$ (7 SAYs), though stock as large as $3785 \mathrm{~cm}^{3}$ (1 gallon) was used (Table 3). Most container stock did not receive preplanting amendments. Year 1 survival of container stock ranged from $14 \%$ to $94 \%$ (median $=59 \%$; weighted average $=57 \%$ ). Survival rates of the SAYs in our study were near the upper end of this range. Long-term survival was reported for only a few SAYs, but was highly variable: survival 5 yr after outplanting ranged from $10 \%$ to $74 \%$.

About equal proportions of the BR studies applied no preplanting amendments, an $\mathrm{H}$ dip, or a mycorrhizal application (Table 4). The BR stock we examined that received no preplanting amendment or received a mycorrhizal application had lower survival rates than similar SAYs monitored in other studies, whereas the BR SAY that received $\mathrm{H}$ application spanned the range of survival rates recorded in other studies. Year 1 survival of BR SAYs ranged from $21 \%$ to $98 \%$ ( median $=56 \%$; weighted average $=48 \%$ ). Survival $4-5 \mathrm{yr}$ after outplanting spanned a comparable range (14-85\%) though again few SAYs were monitored for this long. 
Table 3. Compilation of survival data for Wyoming big sagebrush container stock outplantings, including this study. Data are sorted in order of increasing container volume and planting year.

\begin{tabular}{|c|c|c|c|c|c|c|c|c|c|c|}
\hline \multirow[b]{2}{*}{ Stock $^{1}$} & \multirow[b]{2}{*}{ Year } & \multirow[b]{2}{*}{$N$} & \multicolumn{5}{|c|}{ \% Survival to year: } & \multirow[b]{2}{*}{ Site $^{2}$} & \multirow[b]{2}{*}{ Purpose and amendments, if any } & \multirow[b]{2}{*}{ Source $^{3}$} \\
\hline & & & 1 & 2 & 3 & 4 & 5 & & & \\
\hline Small & 2000 & 1182 & 74 & 53 & -4 & 46 & - & HRNM & $\begin{array}{l}\text { Postfire rehabilitation, } \\
\text { mitigation; W-519 project }\end{array}$ & DS04 \\
\hline Small & 2001 & 941 & 76 & 29 & 28 & - & - & HRNM & Postfire rehabilitation & This study \\
\hline Small & 2002 & 877 & 52 & 44 & 34 & - & - & HRNM & Postfire rehabilitation & $\begin{array}{l}\text { This study; } \\
\text { EL05 }\end{array}$ \\
\hline Small & 2002 & - & 77 & 52 & 50 & 27 & - & HRNM & $\begin{array}{l}\text { Postfire rehabilitation, } \\
\text { mitigation; ERDF Area I project }\end{array}$ & JG06 \\
\hline Small & 2005 & 710 & 37 & 30 & - & - & $19^{5}$ & HRNM & Postfire rehabilitation & $\begin{array}{l}\text { This study; } \\
\text { ES09 }\end{array}$ \\
\hline Small & 2006 & 154 & 27 & 11 & 10 & - & - & Hanford & Mitigation; L-325 project & DS09 \\
\hline Small & 2006 & 232 & 14 & 6 & - & - & - & Hanford & Mitigation; IDF project & DS08 \\
\hline 98 & 2007 & 160 & 33 & - & - & - & - & Idaho & Restoration & H09 \\
\hline Large & 1999 & 433 & 41 & 37 & 36 & - & 36 & HRNM & Mitigation; W-519 project & DSO4 \\
\hline Large & 2001 & 556 & 81 & 37 & 34 & - & - & HRNM & Postfire rehabilitation & This study \\
\hline Large & 2002 & - & 66 & 25 & 21 & 14 & - & HRNM & $\begin{array}{l}\text { Postfire rehabilitation, } \\
\text { mitigation; ERDF Area I project }\end{array}$ & JG06 \\
\hline Large & 2004 & 50 & 94 & 82 & 82 & 82 & 74 & Utah & Restoration & N11 \\
\hline Large & 2005 & 250 & - & - & - & - & 10 & Wyoming & Postfire rehabilitation & W11 \\
\hline Large & 2006 & 250 & - & - & - & 42 & - & Wyoming & $\begin{array}{l}\text { Postfire rehabilitation; } \\
\text { hydrogel amendment }\end{array}$ & W11 \\
\hline Large & 2007 & 250 & - & - & 0 & - & - & Wyoming & Postfire rehabilitation & W11 \\
\hline Large & 2007 & 250 & - & - & 36 & - & - & Wyoming & $\begin{array}{l}\text { Postfire rehabilitation; } \\
\text { hydrogel amendment }\end{array}$ & W11 \\
\hline Large & 2007 & 250 & - & - & 53 & - & - & Wyoming & $\begin{array}{l}\text { Postfire rehabilitation; } \\
\text { mycorrhizal dip amendment }\end{array}$ & W11 \\
\hline Large & 2007 & 250 & - & - & 71 & - & - & Wyoming & $\begin{array}{l}\text { Postfire rehabilitation; } \\
\text { hydrogel and mycorrhizal dip } \\
\text { amendment }\end{array}$ & W11 \\
\hline Large & 2007 & 200 & 73 & 65 & - & - & - & Hanford & Mitigation; L-325 project & DS09 \\
\hline Large & 2007 & 486 & 33 & - & - & - & - & Hanford & Mitigation; IDF project & DS08 \\
\hline Large & 2009 & 432 & 81 & - & 68 & - & - & Oregon & Habitat rehabilitation & D13 \\
\hline 246 & 2007 & 160 & 40 & - & - & - & - & Idaho & Restoration & H09 \\
\hline 344 & 2007 & 160 & 40 & - & - & - & - & Idaho & Restoration & H09 \\
\hline 3785 & 1997 & 293 & 70 & 54 & - & 42 & 37 & Hanford & Mitigation; 300-FF-1 project & $\mathrm{J} 02$ \\
\hline
\end{tabular}

${ }^{1}$ Stock sizes: small $=66-\mathrm{cm}^{3}$ container; $98=98-\mathrm{cm}^{3}$ container; large $=164-\mathrm{cm}^{3}$ container; $246=246-\mathrm{cm}^{3}$ container; $344=344-\mathrm{cm}^{3}$ container; $3785=3785-\mathrm{cm}^{3}$ container.

${ }^{2}$ Site abbreviations: HRNM indicates Hanford Reach National Monument, WA; and Hanford, US Department of Energy Hanford Site, WA.

${ }^{3}$ Sources: D13 indicates Davies et al. (2013); DS04, Durham and Sackschewsky (2004); DS08, Durham and Sackschewsky (2008); DS09, Durham and Sackschewsky (2009); EL05, Evans and Lih (2005); ES09, Easterly and Salstrom (2009); H09, Herriman (2009); J02, Johnson (2002); JG06, Johnson and Gano (2006); N11, Newhall et al. (2011); and W11, Y. Warren, unpubl. data (2011). ${ }^{4}$ - indicates data not available.

${ }^{5}$ Survival to Year 6.

\section{DISCUSSION}

Seedling mortality is generally highest in the first year after planting and diminishes in later years (Tables 3 and 4). Monitoring in the first few years after outplanting can give managers a reasonable prediction of the likelihood of achieving their restoration targets. For example, observations of low survival to Year 1 would logically indicate that supplementary plantings may be necessary to reach target densities. However, our results indicate that decisions about the utility of supplementary plantings would be enhanced if monitoring in Year 1 is expanded to include a simple classification of live plants as healthy or stressed. If most plants are healthy in Year 1, survival to Year 3 would also be expected to be high, whereas additional mortality would be expected if most seedlings are stressed in Year 1 (Fig. 3B). This trend applied to all SAYs for which seedling health was assessed in our study, and may be independent of initial survival from planting to Year 1. For example, plantings under marginal growing conditions may have high initial survival with many stressed plants when monitored in Year 1, or low initial survival but a high proportion of healthy plants because the stressed seedlings have died. Thus, monitoring plant health could inform 
Table 4. Compilation of survival data for Wyoming big sagebrush bare-root outplantings, including this study. Data are sorted by amendment and planting year. Amendment abbreviations as in Table 1.

\begin{tabular}{|c|c|c|c|c|c|c|c|c|c|c|}
\hline \multirow[b]{2}{*}{ Amendment } & \multirow[b]{2}{*}{ Year } & \multirow[b]{2}{*}{ N } & \multicolumn{5}{|c|}{$\%$ Survival to year: } & \multirow[b]{2}{*}{ Site } & \multirow[b]{2}{*}{ Purpose } & \multirow[b]{2}{*}{ Source $^{1}$} \\
\hline & & & 1 & 2 & 3 & 4 & 5 & & & \\
\hline None & 1998 & 500 & 98 & 87 & $-^{2}$ & - & - & Hanford & Mitigation; ERDF Area 2 project & J00 \\
\hline None & 1999 & 109 & 34 & 32 & 29 & - & 28 & HRNM & Mitigation; W-519 project & DS04 \\
\hline None & 2006 & 513 & 21 & 14 & - & - & - & Hanford & Mitigation; IDF project & DS08 \\
\hline None & 2006 & 2424 & - & 14 & - & - & 14 & HRNM & Postfire rehabilitation & $\begin{array}{l}\text { This study; } \\
\text { ES08; ES09 }\end{array}$ \\
\hline None & 2007 & $330^{3}$ & 55 & 22 & 13 & - & - & HRNM & Postfire rehabilitation & $\begin{array}{l}\text { This study; } \\
\text { WP11 }\end{array}$ \\
\hline $\mathrm{H}$ & 1998 & 360 & 64 & - & - & - & - & HRNM & Mitigation & D01 \\
\hline $\mathrm{H}$ & 1999 & 503 & 56 & 52 & 47 & - & 50 & HRNM & Mitigation; W-519 project & DS04 \\
\hline $\mathrm{H}$ & 2000 & 2109 & 78 & 54 & - & 51 & - & HRNM & $\begin{array}{l}\text { Postfire rehabilitation, } \\
\text { mitigation; W-519 project }\end{array}$ & DS04 \\
\hline $\mathrm{H}$ & 2001 & 495 & 72 & 20 & 20 & - & - & HRNM & Postfire rehabilitation & This study \\
\hline $\mathrm{H}$ & 2002 & 722 & 84 & 70 & 53 & - & - & HRNM & Postfire rehabilitation & $\begin{array}{l}\text { This study; } \\
\text { EL05 }\end{array}$ \\
\hline $\mathrm{H}$ & 2007 & $1215^{3}$ & 37 & 12 & 11 & - & - & HRNM & Postfire rehabilitation & $\begin{array}{l}\text { This study; } \\
\text { WP11 }\end{array}$ \\
\hline MD & 2002 & - & 58 & 37 & 28 & 22 & - & HRNM & $\begin{array}{l}\text { Postfire rehabilitation; } \\
\text { ERDF Areas F \& H project }\end{array}$ & JG06 \\
\hline MD & 2007 & $450^{3}$ & 45 & 15 & 11 & - & - & HRNM & Postfire rehabilitation & $\begin{array}{l}\text { This study; } \\
\text { WP11 }\end{array}$ \\
\hline MT & 2007 & $465^{3}$ & 40 & 18 & 11 & - & - & HRNM & Postfire rehabilitation & $\begin{array}{l}\text { This study; } \\
\text { WP11 }\end{array}$ \\
\hline$M^{4}$ & 2000 & 353 & 94 & 87 & - & 85 & - & HRNM & $\begin{array}{l}\text { Postfire rehabilitation, } \\
\text { mitigation; W-519 project }\end{array}$ & DS04 \\
\hline $\mathrm{H}+\mathrm{MD}$ & 2002 & 1282 & 40 & 14 & 11 & - & - & HRNM & Postfire rehabilitation & $\begin{array}{l}\text { This study; } \\
\quad \text { EL05 }\end{array}$ \\
\hline$H+R: S^{5}$ & 1999 & 100 & 50 & 40 & 46 & - & 45 & HRNM & Mitigation; W-519 project & DS04 \\
\hline $\mathrm{H}+\mathrm{soil}^{6}$ & 1999 & 100 & 77 & 69 & 64 & - & 64 & HRNM & Mitigation; W-519 project & DS04 \\
\hline
\end{tabular}

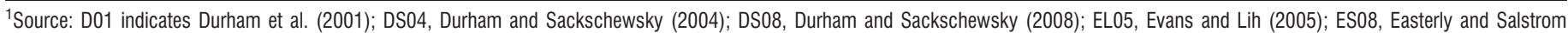
(2008); ES09, Easterly and Salstrom (2009); J00, Johnson et al. (2000); JG06, Johnson and Gano (2006); and WP11, Wirth and Pyke (2011).

2 - indicates data not available.

${ }^{3}$ Initial number of seedlings was estimated from plot size and seeding density.

${ }^{4}$ BioGROW micronized endomycorrhizae.

${ }^{5}$ Stems pruned by $50 \%$ after outplanting to increase root:shoot ratio.

${ }^{6}$ Soil added to hydrogel as mycorrhizal inoculum source.

decisions about when and where supplementary plantings are necessary to achieve target densities.

The outcome of rehabilitation and restoration efforts frequently depends upon factors beyond the control of practitioners (Monsen et al. 2004). Climatic variation, particularly with respect to precipitation, can significantly affect seedling establishment in semiarid environments, and stocktype performance can vary with growing conditions (Barnett and McGilvray 1993). Some planting years in our study experienced above-average annual precipitation after outplanting, and others experienced below-average annual precipitation (supplementary Appendix A; available online at http://dx.doi. org/10.2111/REM-D-12-00114.s1). Annual averages may be misleading in that they can mask intra-annual precipitation patterns (e.g., cumulative precipitation patterns in supplementary Appendix B; available online at http://dx.doi.org/10.2111/ REM-D-12-00114.s2) that may be more strongly related to SAY survival. During the first year after outplanting, for example, seedlings planted in 2002 experienced a wet spring but early and prolonged summer drought, whereas those planted in 2005 experienced a much shorter summer drought.

Differences among sites in characteristics such as soils and vegetation could also have affected seedling performance. For example, higher water stress may be experienced in sandy soils compared to silt loams (Durham et al. 2001), whereas competition from extant vegetation may negatively affect establishment (Newhall et al. 2011; McAdoo et al. 2013). Wildfires are a significant concern in the Columbia Plateau and can directly influence the long-term survival of seedlings; the outcome of restoration efforts in this region may depend as much upon effective fire management as on the technical elements of restoration science (Brooks et al. 2004; Monsen et al. 2004).

Operational decisions such as choice of stock type, preplanting handling conditions, and timing of outplanting can affect survival (Shaw 2004). For example, BR stock is more 
vulnerable than container stock to damage or desiccation during lifting, shipping, and planting (McKay 1997). Although we did not quantitatively assess stock quality, we anecdotally observed some differences in quality among SAYs. For example, the 2006 BR stock was very large, held in storage for an extended period because of adverse planting conditions, and had mold on the leaves and roots at the time of planting (Easterly and Salstrom 2008, 2009).

\section{Performance by Stock and Amendments}

Container stock can be grown in many different cell volumes, and we expected that larger cell volumes would enhance survival (e.g., Herriman 2009). Surprisingly, large and small stock did not clearly differ in the proportion of seedlings that were healthy in Year 1 (Fig. 3) or in survival to Year 3 (Fig. 1). Other published studies also did not indicate clear performance differences among container sizes (Table 3 ).

Survival was more variable for BR stock than for container stock (Fig. 1). Our 2002 BR+H SAY had exceptionally high survival to Year 3 compared to the others we studied and, although we can speculate about reasons for this difference, we lack the replication to examine it rigorously. The 2002 planting year was wetter than other years when BR stock was outplanted (supplementary Appendix A) and more of this precipitation occurred in the spring after outplanting (supplementary Appendix B). Thus the climate may have been more favorable in this than other years, but this is an insufficient explanation, as other stock types planted in this same year did not show the same response. Perhaps this SAY was in better condition or was planted more carefully than the others. It is also worth noting that the survival of this SAY is not unusual compared to other studies (Table 4).

The $\mathrm{H}$ amendment was intended to improve BR performance by decreasing water stress, and survival rates are often higher where it was applied than for untreated SAYs (Table 3). However, its effects were not consistent: although the $\mathrm{BR}+\mathrm{H}$ from the 2002 SAYs had the highest survival of all SAYs, as noted earlier, $\mathrm{H}$ had no effect in other years (Fig. 1). The effectiveness of $\mathrm{H}$ applications may depend on the intra-annual precipitation patterns that occur after planting. For example, seedlings planted in 2002 experienced a wet spring but prolonged summer drought in the year after outplanting (supplementary Appendix B).

Mycorrhizal inoculation had no influence on survival in our 2007 planting year (Fig. 1), yet mycorrhizae generally enhance sagebrush survival and tolerance to moisture stress (Stahl et al. 1998; Durham and Sackschewsky 2004) and other studies reported higher survival rates for inoculated seedlings than we recorded (Tables 3 and 4). We speculate that mycorrhizae may have survived the fire as spores or in association with surviving perennial grasses (Vilarino and Arines 1991), making inoculation unnecessary in this case. Alternatively, the benefits of mycorrhizae may have been of a much smaller magnitude than other factors such as stock quality and planting practice, or the commercial inocula may have been ineffective (e.g., Paluch et al. 2013).

The $2002 \mathrm{BR}+\mathrm{H}+\mathrm{MD}$ stock exhibited unexpectedly low survival despite above-average precipitation that year. $\mathrm{H}$ alone had a strong positive effect on seedling survival in this planting year, as already noted, and it seems unlikely that the addition of mycorrhizae was deleterious to establishment and survival. One other study applied this combination to container stock and reported enhanced survival compared to either amendment alone (Table 3). We conjecture that the double coating of the roots with gel may have resulted in anoxic conditions and tissue death or susceptibility to pathogens after outplanting (Lunt et al. 1973), although we were not able to quantify this.

Previous research (McAdoo et al. 2013) has suggested that outplanting may be a more successful approach than seeding unless competing vegetation is heavily controlled. Although we did not compare outplantings with direct seeding, we expect that outplantings would allow functioning sagebrush habitat to develop more rapidly because they allow seed germination to occur under controlled conditions, and the outplanted individuals are larger and therefore should be better competitors with the extant vegetation.

\section{Economics}

Nursery stock is often perceived to be more expensive than direct seeding (e.g., USDA-NRCS 2006), although to our knowledge these costs have never been explicitly compared. Such comparisons would have to include costs incurred during years when seeding is unsuccessful because of inadequate site preparation and/or climatic conditions (Lambert 2005; Shaw et al. 2005). Using nursery-grown stock should reduce the likelihood of these failures, because germination occurs under controlled conditions in the nursery. Unit costs are also reduced when nursery-grown stock is used in large projects; the most expensive of our SAYs were those produced in small quantities (Tables 1 and 2). Finally, direct-seeding options can be limited by topography (Lysne and Pellant 2004), and outplanting is more appropriate where, as in our study, the goal is restoration of a shrub layer while avoiding mechanical disturbance to native herbaceous vegetation, biological soil crusts, and cultural sites.

Costs varied considerably among stock types, with patterns depending on which cost metric was used. For example, large container stock cost 1.5 times more than any other stock type per planted seedling, but was the second cheapest per surviving plant. Overall, container stock and the $\mathrm{BR}+\mathrm{H}$ stock types appeared to be the most ecologically and economically effective, as they had high survival rates and comparatively low costs per surviving plant (Fig. 4). Which stock type to use may depend on the scope of a given project and on available seedling production facilities. On large projects, for example, BR stock may be preferable if nurseries have greater capacity to scale up its production compared to container stock. Container stock, by virtue of the higher level of control exerted over its growing environment, can more easily be manipulated to achieve desired morphological characteristics such as a minimum root collar diameter (Herriman 2009). It is important that seedling stock specifications are clearly enunciated and that stock be graded to ensure it meets these criteria.

Although we compared costs on a per-plant basis, land managers often plan and budget on a per-unit-area basis. Our results can be easily incorporated into such decisions by adjusting planting densities based on expected per-plant costs and survival rates. For example, more seedlings could be 
planted if they are cheap but have low expected survival, or fewer seedlings could be planted if they are expensive but have better expected survival.

Our economic comparisons were based solely on seedling survival, but it is also important to consider the longer-term performance of seedlings, including how much time elapses before they begin to provide significant habitat structure. In addition, the development of reproductively mature plants is essential for the recovery of shrub-steppe vegetation and expansion of sagebrush into unplanted areas. Outplanted nursery seedlings can provide these functions within several years of planting. For example, Durham and Sackschewsky (2004) reported that $80 \%$ of plants were flowering within $5 \mathrm{yr}$ after outplanting, and Lindsey and Johnson (2010) noted that many container stock were flowering $4 \mathrm{yr}$ after outplanting. The oldest plants in this study were monitored $8 \mathrm{yr}$ after outplanting; while monitoring these plants we observed successful reproduction around them. The rate at which ecosystem functions develop may differ among stock types and sites, but few studies have quantified long-term development of habitat structure and even fewer have compared this development among stock types. Further study of the rate at which habitat structure develops, and its variability among stock and planting years, is clearly warranted.

\section{MANAGEMENT IMPLICATIONS}

To our knowledge, this study spans the widest breadth of sites, stock types, and planting years for Wyoming big sagebrush of any study to date. We also utilized operational data to provide a realistic assessment of planting techniques and costs. Our results agree with a growing body of work (e.g., Davies et al. 2013; McAdoo et al. 2013) indicating that outplanted seedlings can be a valuable tool in the establishment of Wyoming big sagebrush and the restoration of shrub-steppe ecosystems. Container stock and BR stock that received an $\mathrm{H}$ dip before outplanting were the most ecologically and economically effective combinations of stock type and amendment, as they resulted in the highest survival and lowest cost per surviving plant. Container stock exhibited more consistent survival among years than BR stock. Monitoring seedling survival and health in the first year after planting can provide insight into future stand conditions. In our study, mycorrhizal inoculation did not improve the performance of BR stock planted within otherwise intact native plant communities.

Although there is a growing recognition in ecology of the value of shared data (e.g., Hampton et al. 2013), our ability to compare stock types and amendments was limited by the availability of information about the many factors that can affect the performance of outplantings. In our experience, operational plantings often either do not collect or do not consistently report explanatory variables such as stock quality, site conditions, and weather at the time of planting, or measures of planting effectiveness such as plant health in Year 1, long-term survival, and the development of habitat structure of sagebrush outplantings. Documentation of these variables in a clear and consistent fashion would provide valuable support for future studies and meta-analyses explaining variation in seedling performance. Our ability to compare stock types and amendments was also limited compared to what is possible with a rigorous experimental approach; experimental tests of our conclusions by, for example, testing multiple stock types on the same site, would be beneficial. Together, sharing consistent data and using an experimental approach would help land managers and restoration practitioners maximize the success of outplanting efforts.

\section{ACKNOWLEDGMENTS}

We thank Marita Lih, Lorna Emerich, Elaine Boyd, and several others for assistance with data collection. Logistical support was provided by the US Fish and Wildlife Service (USFWS) at the Mid-Columbia River National Wildlife Refuge Complex, and by Kevin Goldie in particular. We thank Yvonne Warren for providing unpublished survival data, Ryan Haugo for assistance with an early analysis, and David Briske, Sue Phillips, Steve Windhager, and several reviewers for feedback on earlier versions of this article.

\section{LITERATURE CITED}

AugustinE, D. J. 2010. Spatial versus temporal variation in precipitation in a semiarid ecosystem. Landscape Ecology 25:913-925.

Barnett, J. P., and J. M. McGilvray. 1993. Performance of container and bareroot Ioblolly pine seedlings on bottomlands in South Carolina. Southern Journal of Applied Forestry 17:80-83.

Boyd, C. S., And K. W. Davies. 2012. Spatial variability in cost and success of revegetation in a Wyoming big sagebrush community. Environmental Management 50:441-450.

Brooks, M. L., C. M. D’Antonio, D. M. Richardson, J. B. Grace, J. E. Keeley, J. M. Ditomaso, R. J. Hobbs, M. Pellant, and D. Pyke. 2004. Effects of invasive alien plants on fire regimes. BioScience 54:677-688.

Connelly, J. W., M. A. Schroeder, A. R. Sands, and C. E. Braun. 2000. Guidelines to manage sage grouse populations and their habitats. Wildlife Society Bulletin 28:967-985.

Crawley, M. L. 2007. The R book. West Sussex, England: John Wiley and Sons. 942 p.

Davies, G. M., J. D. Bakker, E. Dettweller-Robinson, P. W. Dunwidie, S. A. Hall, J. Downs, AND J. Evans. 2012. Trajectories of change in sagebrush steppe vegetation communities in relation to multiple wildfires. Ecological Applications 22:15621577.

Davies, K. W., C. S. Boyd, and A. M. Nafus. 2013. Restoring the sagebrush component in crested wheatgrass-dominated communities. Rangeland Ecology \& Management 66:472-478.

Durham, R. E., and M. R. SAckschewsky. 2004. W-519 sagebrush mitigation project, FY-2004 final review and status. Richland, WA, USA: Pacific Northwest National Laboratory. PNNL-14901. 59 p.

DuRham, R. E., AND M. R. SACKSCHEWSKY. 2008. IDF sagebrush habitat mitigation project: FY2008 compensation area monitoring report. Richland, WA, USA: Pacific Northwest National Laboratory. PNNL-17927. 9 p.

DuRham, R. E., and M. R. SACKSCHEWSKY. 2009. L-325 sagebrush habitat mitigation project: FY2009 compensation area monitoring report. Richland, WA, USA: Pacific Northwest National Laboratory. PNNL-18824. 8 p.

Durham, R. E., B. A. Zamora, M. R. Sackschewsky, and J. C. Ritter. 2001. Predicting first-year bare-root seedling establishment with soil and community dominance factors. In: E. D. McArthur and D. J. Fairbanks [compilers]. Shrubland Ecosystem Genetics and Biodiversity: Proceedings; 13-15 June 2000; Provo, UT, USA. Ogden, UT, USA: US Department of Agriculture, Forest Service. RMRS-P-21. p. 204-209.

EAsterly, R., and D. Salstrom. 2008. Vegetation rehabilitation monitoring: 2005 McLane Wildfire, Hanford Reach National Monument, Washington. Bellingham, WA, USA: SEE Botanical Consulting. $30 \mathrm{p}$. 
Easterly, R., and D. Salstrom. 2009. 2005 Weather Station Fire: BAER rehabilitation vegetation monitoring, Hanford Reach National Monument, Washington. Bellingham, WA, USA: SEE Botanical Consulting. $56 \mathrm{p}$.

Evans, J. R., AND M. P. LIH. 2005. Recovery and rehabilitation of vegetation on the Fitzner-Eberhardt Arid Lands Ecology Reserve, Hanford Reach National Monument, following the 24 Command Fire; final report: 2001-2004. Seattle, WA, USA: The Nature Conservancy. $254 \mathrm{p}$.

Hampton, S. E., C. A. Strasser, J. J. Tewksbury, W. K. Gram, A. E. Budden, A. L. Batcheller, C. S. Duke, and J. H. Porter. 2013. Big data and the future of ecology. Frontiers in Ecology and the Environment 11:156-162.

[HMS] Hanford Meteorological Station. 2011. Available at: http://www.hanford.gov/ hms/. Accessed 16 August 2011.

HerRIMAN, K. R. 2009. Wyoming big sagebrush: efforts towards development of target plants for restoration [thesis]. Moscow, ID, USA: University of Idaho. 63 p.

JoHNSON, A. L. 2002. 2002 environmental restoration contractor revegetation monitoring report. Richland, WA, USA: Bechtel Hanford, Inc., BHI-01659. 67 p.

Johnson, A. L., and K. A. Gano. 2006. 2006 river corridor closure contractor revegetation and mitigation monitoring report. Richland, WA, USA: Washington Closure Hanford LLC. WCH-133. 94 p.

Johnson, A. L., K. A. Gano, and J. K. Linville. 2000. 2000 environmental restoration contractor revegetation monitoring report. Richland, WA, USA: Bechtel Hanford, Inc. BHI-01406. $122 \mathrm{p}$.

LAMBERT, S. M. 2005. Seeding considerations in restoring big sagebrush habitat. In: N. L. Shaw, M. Pellant, and S. B. Monsen [compilers]. Sage-grouse habitat restoration symposium proceedings; 4-7 June 2001; Boise, ID, USA. Fort Collins, CO, USA: US Department of Agriculture, Forest Service. RMRS-P-38. p. $75-80$.

LINDSEY, C. T., AND A. L. JoHnson. 2010. 2010 river corridor closure contractor revegetation and mitigation monitoring report. Richland, WA, USA: Washington Closure Hanford LLC. WCH-428. 166 p.

Link, S. O., G. W. Gee, M. E. Theide, And P. A. Beedlow. 1990. Response of a shrubsteppe ecosystem to fire: soil, water, and vegetational change. Arid Soil Research and Rehabilitation 4:163-172.

Longland, W. S., and S. L. Bateman. 2002. The ecological value of shrub islands on disturbed sagebrush rangelands. Journal of Range Management 55:571-575.

Lunt, O. R., J. LeteY, AND S. B. Clark. 1973. Oxygen requirements for root growth in three species of desert shrubs. Ecology 54:1356-1362.

Lysne, C. R., And M. Pellant. 2004. Establishment of aerially seeded big sagebrush following southern Idaho wildfires. Boise, ID, USA: US Department of Interior, Bureau of Land Management, Technical Bulletin 2004-01. 14 p.

MacDougall, A. S., S. D. Wilson, And J. D. Bakker. 2008. Climatic variability alters the outcome of long-term community assembly. Journal of Ecology 96:346-354.

McAdoo, J. K., C. S. Boyd, And R. L. Sheley. 2013. Site, competition, and plant stock influence transplant success of Wyoming big sagebrush. Rangeland Ecology \& Management 66:305-312.

McKay, H. M. 1997. A review of the effect of stresses between lifting and planting on nursery stock quality and performance. New Forests 13:369-399.

Monsen, S. B., R. Stevens, and N. L. Shaw. 2004. Restoring western ranges and wildlands. Three volumes. Fort Collins, C0, USA: US Department of Agriculture, Forest Service. RMRS-GTR-136. $884 \mathrm{p}$.

Newhall, R. L., V. P. Rasmussen, and B. M. Kitchen. 2011. Introducing big sagebrush into a crested wheatgrass monoculture. Natural Resources and Environmental
Issues 17:article 26. Available at: http://digitalcommons.usu.edu/nrei/vol17/iss1/ 26. Accessed 4 January 2012.

[NSBAER] North States Burned Area Emergency Rehabilitation Team. 2000. 24 Command Fire, Benton County, Washington, June-July 2000, Burned area emergency rehabilitation plan. Available at: www.fws.gov/fire/downloads/ ES_BAR/Plan_24Command. PDF. Accessed 21 June 2013.

Paluch, E. C., M. A. Thomsen, and T. J. Volk. 2013. Effects of resident soil fungi and land use history outweigh those of commercial mycorrhizal inocula: testing a restoration strategy in unsterilized soil. Restoration Ecology 21:380-389.

R Core Team. 2013. R: A language and environment for statistical computing. Available at: http://www.R-project.org. Accessed 26 August 2013.

Schuman, G. E., L. E. Vicklund, And S. E. Belden. 2005. Establishing Artemisia tridentata ssp. wyomingensis on mined lands: science and economics. Arid Land Research and Management 19:353-362.

SHAW, N. L. 2004. Production and use of planting stock. In: S. B. Monsen, R. Stevens, and N. L. Shaw [compilers]. Restoring western ranges and wildlands. 3 volumes. Fort Collins, C0, USA: US Department of Agriculture, Forest Service, RMRS-GTR136. p. $745-768$.

Shaw, N. L., A. M. DeBolt, and R. Rosentreter. 2005. Reseeding big sagebrush: techniques and issues. In: N. L. Shaw, M. Pellant, and S. B. Monsen [compilers]. Sage-grouse habitat restoration symposium proceedings; 2001 June 4-7; Boise, ID, USA. Fort Collins, C0, USA: US Department of Agriculture, Forest Service, RMRS-P-38. p. 99-108.

Stahl, P. D., G. E. Schuman, S. M. Frost, and S. E. Willams. 1998. Arbuscular mycorrhizae and water stress tolerance of Artemisia tridentata ssp. wyomingensis seedlings. Soil Science Society of America Journal 62:1309-1313.

[USDA-NRCS] US Department of Agriculture-Natural Resources Conservation Service. 2006. Big sagebrush Artemisia tridentata Nuttall. Available at: http://plants.usda. gov/plantguide/pdf/pg_artrw8.pdf. Accessed 9 August 2011.

[US EPA] US Environmental Protection Agency. 2010. Ecoregions of Washington. Available at: http://www.epa.gov/wed/pages/ecoregions/wa_eco.htm. Accessed 4 February 2012.

Vander Haegen, W. M., F. C. Dobler, and D. J. Pierce. 2000. Shrub-steppe bird response to habitat and landscape variables in Eastern Washington, U.S.A. Conservation Biology 14:1145-1160.

VILARINO, A., AND J. ARINES. 1991. Numbers and viability of vesicular-arbuscular fungal propagules in field samples after wildfire. Soil Biology and Biochemistry 23:1083-1087.

WeLCH, B. L. 2005. Big sagebrush: a sea fragmented into lakes, ponds, and puddles. Fort Collins, CO, USA: US Department of Agriculture, Forest Service, RM-GTR144. $210 \mathrm{p}$.

Wijayratne, U. C., and D. A. Pyke. 2012. Burial increases seed longevity of two Artemisia tridentata (Asteraceae) subspecies. American Journal of Botany 99:438-447.

WiRTh, T. A., And D. A. Pyke. 2011. Effectiveness of post-fire seeding at the FitznerEberhardt Arid Land Ecology Reserve, Washington. Corvallis, OR, USA: US Department of the Interior, US Geological Survey. Open-File Report 2011-1241. $42 \mathrm{p}$.

Young, J. A., and R. A. Evans. 1989. Dispersal and germination of big sagebrush (Artemisia tridentata) seeds. Weed Science 37:201-206. 